\title{
AN ANALYSIS OF DEIXIS IN PAMUNGKAS' "ONE ONLY" SONG LYRICS
}

\author{
Siti Kusumadewi ${ }^{1}$, Anita Anggraeni² \\ ${ }^{1}$ IKIP Siliwangi \\ ${ }^{2}$ IKIP Siliwangi \\ ${ }^{1}$ siti.kusumadewi@student.ikipsiliwangi.ac.id, ${ }^{2}$ anitaenglish26@gmail.com
}

\begin{abstract}
The aims of this research are to analyze the kinds of deixis that are used in One Only song lyrics and to find out the types of deixis that are major used in in the song lyrics. The researcher choose this song because this song is easy to listen to and got a good response from the listener. This research used qualitative research. The result of this research showed that in the One Only song lyrics there are four kinds of deixis, there are personal deixis, spatial deixis, temporal deixis and social deixis. Based on the discussion, personal deixis came as the most often appears deixis with 50 deictic words found or 92.6 $\%$, the second is Spatial deixis (2 deictic words or $3.7 \%$ ), followed by temporal deixis and social deixis with the percentage of $1.85 \%$ each.
\end{abstract}

Keywords: Deixis, Song Lyrics, Pamungkas

\section{INTRODUCTION}

Language is one of the way for human to communicate. It is not only as a communication tools, but also in the form of arts that we could met in our daily life, such as advertisement and entertainment, such as poem, drama, and music. Music cannot be separated from our daily lives. Justin \& Sloboda (2010) in Nasution, Setiadi, \& Ilza (2018) described that music is the language of emotions. Music itself becomes a means of communication, through the lyrics delivered by the singer that contains the meaning that the singer want to convey. Raj \& Muniapan (2012) cited in Nasution et al., (2018) stated that music is not only listened as a hobby or favorite activity but it also considered as a friend to accompany in doing a lot of activities such as working, studying or even thinking, especially for teenagers. Most of music will be liked by the listeners if the content of the song has its own meaning for the listener, so that's why the song creator isn't carelessly in making the lyric (Nasution et al., 2018). In understanding the meaning of the song being listened to, there are several aspects that we need to know that we can find out through deixis.

Deixis derived from the Greek word 'deiktikos' that means pointing or indicating. Deixis is the essential part of pragmatics. Sobur (2006) cited in Damayanti (2019) stated that pragmatics is the study of meaning in relation to speech situations. Yule (1996) in Hidayah (2019), said that deixis is one of the most basic things in technical term of utterances. In additions, (Apu et al., 2019) stated that deixis is a form of language in the form of words or the other that serves as a clue to a variable reference. It could be described as deixis is a words or a language form that tells something different depending on the situations. It helps to understand the use of language in communication. According to Bauer (2012:3) as cited in Aprianti and Parmawati (2020) "linguistics is the word meaning 'relating to language' as well as word meaning 'relating to linguistics'. 
Here, the researcher was interested to conduct a study in analyzing deixis in the song lyrics. Song lyrics was chosen because it usually have a meaning that the singer or the songwriter want to share or conveyed to the listener. The song that was chosen as the object of this study entitled One Only by Indonesian singer Pamungkas. Ardhyanti \& Supriyatiningsih (2020) stated that "song is a poem that uses music and uses the figurative language in its lyrics, and lyrics is a component on song which like a stories or conversation between people".

\section{Types of Deixis}

Alan Cruse (2000) cited in Nasution et al., (2018) categorized deixis into five types, they are: Personal deixis, spatial or place deixis, temporal or time deixis, discourse deixis, and social deixis.

\section{Personal Deixis}

Personal deixis derived from Greek word 'prosopon' which means mask, countenance, or role. Eragbe et al., (2015) in Setiakawanti \& Susanti (2018) stated that pronouns such as the first, second and third used as a means of locating the referents in relations to the events taking place in the discourse are called personal deixis. Personal Deixis is determined according to the participant's role in the language event. The participant's role consists of three categories. They are first person 'I' (singular) and 'we' (plural); second person 'you'; and third person 'he/she' (singular), and 'they' (plural).

\section{Spatial Deixis}

Wiguna et al., (2018) stated that "Place Deixis is an expression used to show the location relative to the location of a participant in the speech even". Spatial deixis or place deixis is used to point to location related to the speaker, such as here, there, this and that.

\section{Temporal Deixis}

Temporal deixis is used to point to the time. There are three major divisions of the time deixis, first, before the moment of utterance; second, at the time of utterance; third, after the time of utterance. The only pure English temporal deictic words are "now" which designates a period overlapping with the time of speaking, so which basically means "not now" and might point either into future or the past.

\section{Social Deixis}

Social deixis used to point out at the social characteristics of, or distinctions between, the participants or referents in a speech event. Levinson (1985) in Noerrofi'a \& Bahri (2019) said that "social deixis concerned with the encoding of destination that are relative to participant roles, particularly aspect of the social relationship holding between speaker and addressee (s)."

\section{Discourse Deixis}

Wiguna et al., (2018) explained that "Discourse deixis serves to facilitate the interpretation or understanding the discourse, both written and oral discourse". In addition, Apu et al., (2019) stated that discourse deixis relates to the use of an expression in an utterance to refer to a part of the discourse that contains the utterance (the term itself means). We can also include in the deixis of discourse a number of other ways in which an utterance signifies its relationship with the text that surrounds it.

\section{Pamungkas}

Rizky Pamungkas, well known as Pamungkas, is Indonesian newcomer singer who carries the genre of modern folk pop music. He first debuted in 2018 by making an album of his own 
entitled "Walk The Talk". Not only came as a solo singer, Pamungkas was a musician who produced his own music, wrote song lyrics, designed and edited, and designed his own album.

\section{METHOD}

The researcher used descriptive qualitative as the method for this research. According to Ospina (2004, cited in Kuswandi \& Apsari, 2019), qualitative research as a form of systematic empirical inquiry into meaning. This study discussed about what type of deixis and what the dominant type of deixis that shows on Pamungkas's One Only song lyrics. The instrument that the researcher used in this study was the researcher herself. The data was taken from singer Pamungkas's song lyrics entitled One only that was released in 2018 from the internet. In collecting the data, the researcher used four steps. First, the researcher listened to the song; second, the researcher searched the song lyrics of One Only by Pamungkas on the internet; third, the researcher mark the deictic expression found in the lyrics; and last, the researcher categorized the data into their types of deixis. They are personal deixis (first, second, and third person deixis), spatial deixis, and temporal deixis.

\section{RESULTS AND DISCUSSION}

\section{Results}

The objective of this research is to find and analyze what kind of deixis that was found in Pamungkas's song lyrics "One Only". The researcher found that there are five types of deixis in the song lyrics. They are personal deixis, spatial deixis, temporal deixis, discourse deixis and social deixis.

Table 1. Deixis frequency in One Only song lyrics by Pamungkas

\begin{tabular}{|c|c|c|c|c|c|}
\hline No & Type of Deixis & Deictical word & Quantity & Total & Percentage \\
\hline \multirow[t]{4}{*}{1} & Personal & $\mathrm{I}$ & 19 & 50 & $92.6 \%$ \\
\hline & & You & 20 & & \\
\hline & & $\mathrm{Me}$ & 8 & & \\
\hline & & My & 3 & & \\
\hline \multirow[t]{2}{*}{2} & Spatial & There & 1 & 2 & $3.7 \%$ \\
\hline & & Here & 1 & & \\
\hline 3 & Temporal & Now & 1 & 1 & $1.85 \%$ \\
\hline 4 & Social & Love & 1 & 1 & $1.85 \%$ \\
\hline
\end{tabular}

\section{Discussion}

After conducting the research the researcher found that the dominant deixis in Pamungkas's One Only song lyrics is personal deixis. It was shown that there are 50 personal deixis ,that representated by the word I, me, my, and you. It also shown that personal deixis appears in almost every lyrics of the song. The second is spatial deixis representated by the word here and there, while there is only one word included in temporal deixis and one word in social deixis.

\section{Personal Deixis}

From the table above, it can be seen that in One Only song lyrics, there are two types of personal deixis, the first person deixis and second person deixis. The researcher found four words that belong to personal deixis, three words as first person deixis (I, My and Me), and one word as second person deixis (You). For example, in the lyrics "You tell me what did I do", includes 
two kinds of first person deixis (I and Me) and one kind of second person deixis (You). First person deixis, "I", refers to the speaker or the singer as the subject. Then, "me" in the lyrics refers to the speaker as the object. Last, "You", second person deixis, refers to the girl. Meanwhile, the third person deixis did not found in this song. The researcher found a total of 50 personal deixis data from the lyrics of the song One Only.

\section{Spatial Deixis}

Spatial deixis is refer to the spatial location that is relevant to the utterance. As seen in the table above, the writer found two words that indicate spatial deixis in the One Only song lyrics, that is the use of word "there" and "here". The word "there" in the lyrics "Oo, there you are" refers to the place where the girl (you), which is away from the speaker. Meanwhile, the word "here" in the lyrics "While I'm, here I am", refer to the location of the speaker (I) where he staring at the girl. It can be seen from the next lyrics which read "sitting still stare at you only".

\section{Temporal Deixis}

The researcher found one data of temporal deixis, that is "now". In the lyrics "to get you now" as time deixis that described how the speaker is felt like he is the luckiest person at the moment because he have the girl, as the previous lyrics stated "Well, I'm luckiest".

\section{Social Deixis}

Hornby (1995) (cited in Ainiyah et al., (2019)) explains that there are three aspects that influencing social deixis. They are distance (means that there is a lack of friendly feelings in personal relationship), power (used for person, group, or state with a great authority or influence), and social (concerns on the rank and position within society). In other words, social deixis refers to the interpersonal relationship between the speaker and addressee. The researcher found one social deixis, "Love", in the song lyrics. The lyrics said "to be with you, Love". The deictic word "Love" was used as an expression of love from the speaker to the girl.

\section{CONCLUSION}

Based on the data and the explanation above, the types of deixis that was found in the lyric were personal deixis, spatial deixis, temporal deixis and social deixis. The third person type of deixis as well as discourse deixis was not found in the lyrics. As for the dominant deixis in the song lyrics of "One Only" by Pamungkas is personal deixis.

\section{ACKNOWLEDGMENTS}

The writer want to thank Allah SWT, writer friends and family for the continuous encouragement, also the writer want to thank to our lecturer for the kind advice and help.

\section{REFERENCES}

Ainiyah, K., Sili, S., \& Ariani, S. (2019). Analysis Of Deixis In Pitch Perfect 2 Movie. Jurnal Ilmu Budaya, 3(3), 288-302.

Aprianti, I. N., \& Parmawati, A. (2020). Derivational And Inflectional Morpheme Analysis On The Song Lyrics Of Lady Gaga "A Star Is Born” Album. Project (Professional Journal Of English Education), 3(3), 322-328.

Apu, F., Yani Konisi, L., Yunus, Dan, Jurusan Pend Bahasa Dan Sastra Indonesia, A., Jurusan Pendidikan Bahasa Dan Sastra Indonesia, D., \& Keguruan Dan Ilmu, F. (2019). Deiksis Dalam Wacana Narasi Buku Siswa Bahasa Indonesia Smp Kelas Vii Revisi 2017 Oleh. 
Bahasa Dan Sastra), 4(1), 2503.

Ardhyanti, S. V., \& Supriyatiningsih, S. (2020). Figurative Language Analysis In Celine Dion's Song Lyrics Falling Into You Album. Project, 3(1), 11-19.

Damayanti, R. (2019). Pemaknaan Pragmatik Dalam Teks Meme Di Instagram. 2, 46-58.

Hidayah, A. (2019). A Deixis Analysis Of Song Lyrics In Back To You. Surakarta, 2(2), $47-$ 55.

Kuswandi, M., \& Apsari, Y. (2019). An Analysis Of Pauses, Overlaps And Backchannels In Conversation In Vlog By Nessie Judge. Project (Professional Journal Of English Education), 2(3), 282-291.

Nasution, D. R. A., Setiadi, G., \& Ilza, S. S. (2018). Deixis Analysis In The Song Lyrics Of Ed Sheeran's Divide Album. 2.

Noerrofi'a, I., \& Bahri, S. (2019). The Analysis Of Social Deixis In The Movie Beauty And The Beast. Pioneer, 11(1), 12-20.

Setiakawanti, R. N., \& Susanti, E. (2018). Analysis Pragmatic Study On Deixis In The Articles Jakarta Sport. Project, 1(6), 757-762.

Wiguna, A., Anggraeni, H., Nuramalia, R., \& Sadikin, I. S. (2018). Deixis In Maleficent Movie Script. Project, 1(2). 